\title{
ANALISIS KOMPARASI USAHATANI PADI SEMI ORGANIK DAN NON ORGANIK DI KECAMATAN UNDAAN KABUPATEN KUDUS
}

\section{(Comparative Analysis Of Semi Organic And Non Organic Paddy Comparative In Sub District Undaan Kudus Regency)}

\author{
D. I. A. Pratama, B. M. Setiawan, dan E. Prasetyo \\ Fakultas Peternakan dan Pertanian, Universitas Diponegoro \\ Email: donyindraadipratama@gmail.com
}

Diterima 11 Juli 2017, disetujui 23 November 2017

\begin{abstract}
ABSTRAK
Penelitian bertujuan mengidentifikasi komponen dan kuantitas faktor produksi, menganalisis perbandingan produksi, biaya produksi, serta pendapatan pada usahatani padi semi organik dan non organik. Lokasi penelitian di Kecamatan Undaan Kabupaten Kudus. Penelitian dilakukan menggunakan metode survei. Pengambilan responden dilakukan secara acak untuk responden petani padi non organik sebanyak 41 orang dari populasi sebanyak 410 orang dan sensus untuk responden petani padi semi organik diambil sebanyak 15 orang. Alat analisis yang digunakan adalah analisis pendapatan (finansial usaha) dan uji beda independent sampel t-test. Hasil penelitian menunjukkan bahwa komponen faktor-faktor produksi yang digunakan pada usahatani padi semi organik maupun non organik adalah luas lahan, benih, pupuk, pestisida, dan tenaga kerja. Pupuk dan pestisida yang digunakan pada usahatani padi semi organik sebagian besar menggunakan bahan-bahan organik namun masih dipadu dengan bahan non organik (kimia). Hasil analisis menunjukkan bahwa kuantitas rata-rata faktor produksi lahan, benih, pupuk, dan tenaga kerja (HKP) tidak ada perbedaan nyata, sedangkan perbandingan antara biaya produksi dan penerimaan usahatani padi semi organik dan non organik menunjukkan adanya perbedaan yang nyata, dan untuk produksi dan pendapatan tidak ada perbedaan yang nyata.
\end{abstract}

Kata Kunci: usahatani, padi, organik, faktor produksi

\begin{abstract}
This study aimed to identify the components and quantities of production factors, to analyze the ratio of production, production cost, and income on semi-organic and non-organic paddy farming. Research location was in Undaan District Kudus Regency. The research was conducted using survey method. Respondents were collected randomly with total of nonorganic rice farmers as many as 41 people from the population of 410 people and census for semi-organic rice farmers of 15 respondents. Earnings analysis (business finance) and independent test of sample t-test were used to analyze. The results showed that the components of production factors used in semi-organic and non-organic paddy farming are land, seed, fertilizer, pesticide, and labor. Fertilizers and pesticides used in semi-organic rice farming mostly use organic materials but still combined with non-organic materials (chemical). The results indicate that the average quantity of land, seed, fertilizer and labor (HKP) production factors is not significantly different. Meanwhile the comparison between production cost and
\end{abstract}


the acceptance of semi-organic and non-organic paddy farming showed a significant difference, and for production and income showed no significant difference.

Keywords: paddy, farming, organic, production factors

\section{PENDAHULUAN}

Pertanian semi organik merupakan sebuah langkah awal untuk menjadi pertanian organik. Hal ini karena produk pertanian yang ada pada umumnya masih banyak mengandung bahan-bahan kimia, dimana kandungan bahan kimia tersebut dapat berdampak negatif pada kesehatan tubuh manusia sebagai konsumennya. Bahan kimia yang seringkali digunakan oleh petani terdapat pada pestisida dan pupuk. Penggunaan bahan kimia juga dapat memacu perubahan keseimbangan ekosistem serta perubahan sifat kimia, fisika, dan biologi pada tanah. Produktivitas lahan pada akhirnya akan mengalami penurunan karena kondisi tanah yang rusak (Suhartini, 2013).

Sejalan dengan kesadaran masyarakat untuk mengkonsumsi makanan yang lebih sehat dan bergizi, maka dimulailah langkah awal untuk menuju pertanian organik yaitu dengan melalui pertanian semi organik khususnya pada komoditas tanaman padi. Pertanian semi organik dalam pengelolaannya pada sebagian besar faktor produksi seperti pupuk dan pestisida menggunakan bahanbahan organik. Namun masih tetap dipadukan dengan faktor produksi non organik buatan pabrik baik pada pupuk maupun pestisida. Pupuk organik dan pestisida alami dapat dibuat sendiri oleh petani dengan biaya yang lebih rendah namun masih terkendala bahan baku, sedangkan pupuk dan pestisida (kimia) buatan pabrik terkendala dengan harga produk yang mahal yang kurang sesuai dengan kemampuan ekonomi petani.

Kendala yang dialami petani dalam pertanian semi organik adalah besarnya investasi lahan yang tinggi, tidak banyak dan

Tabel 1. Jumlah Responden Berdasarkan Tingkat Pendidikan

\begin{tabular}{llcccc}
\hline \multirow{2}{*}{ No } & \multirow{2}{*}{ Tamatan Sekolah } & \multicolumn{2}{c}{ UT Padi Semi Organik } & \multicolumn{2}{c}{ UT Padi Non Organik } \\
& & Jumlah & Persentase & Jumlah & Persentase \\
\hline & & ----orang---- & $----\% 0^{----}$ & --- orang---- & $----\%$---- \\
1 & SD/MI & 11 & 73 & 23 & 56 \\
2 & SMP/MTS & 3 & 20 & 7 & 17 \\
3 & SMA/MA & 1 & 7 & 8 & 20 \\
4 & D3/ S-1 & 0 & 0 & 3 & 7 \\
\hline \multicolumn{1}{c}{ Jumlah } & 15 & 100 & 41 & 100 \\
\hline
\end{tabular}

Sumber: Data Primer, 2016.

Tabel 2. Jumlah Responden Berdasarkan Usia

\begin{tabular}{cccccc}
\hline \multirow{2}{*}{ No } & \multirow{2}{*}{ Usia } & \multicolumn{2}{c}{ UT Padi Semi Organik } & \multicolumn{2}{c}{ UT Padi Non Organik } \\
& & Jumlah & Persentase & Jumlah & Persentase \\
\hline & & ---- orang---- & $----\%$---- & ---- orang---- & $----\%----$ \\
1 & $30-40$ & 2 & 13 & 5 & 12 \\
2 & $41-50$ & 3 & 20 & 11 & 27 \\
3 & $51-60$ & 10 & 67 & 17 & 41 \\
4 & $>60$ & 0 & 0 & 8 & 20 \\
\hline & Jumlah & 15 & 100 & 41 & 100 \\
\hline
\end{tabular}

Sumber: Data Primer, 2016. 
Tabel 3. Luas Lahan Petani Responden

\begin{tabular}{cccccc}
\hline \multirow{2}{*}{ No } & $\begin{array}{c}\text { Luas lahan } \\
\left(\mathrm{m}^{2}\right)\end{array}$ & \multicolumn{2}{c}{ UT Padi Semi Organik } & \multicolumn{2}{c}{ UT Padi Non Organik } \\
& Jumlah & Persentase & Jumlah & Persentase \\
\hline \multirow{2}{*}{1} & $\leq 5.000$ & ---- orang---- & $----\%$---- & ----orang---- & $----\%$---- \\
2 & $5.001-10.000$ & 0 & 0 & 3 & 7 \\
3 & $10.001-20.000$ & 8 & 53 & 13 & 32 \\
4 & $\geq 20.001$ & 3 & 27 & 12 & 29 \\
\hline & Jumlah & 15 & 100 & 13 & 32 \\
\hline
\end{tabular}

Sumber: Data Primer, 2016.

tidak mudah untuk menemukan luas lahan yang dalam kondisi baik atau tidak banyak tercemar oleh bahan kimia, serta lokasi lahan yang jauh dan tidak strategis. Selain itu, tingginya biaya produksi dan rendahnya produktivitas menyebabkan belum banyak petani yang termotivasi untuk memproduksi padi semi organik (Suratiyah, 2008). Adapun usahatani padi non organik masih banyak dilakukan oleh petani karena produktivitas yang tinggi dan harga yang terjangkau sehingga masih banyak konsumen yang menyukai padi non organik. Tujuan dari penelitian ini adalah untuk mengidentifikasi komponen dan kuantitas faktor - faktor produksi yang digunakan usahatani padi semi organik dan padi non organik dalam satu musim tanam, menganalisis perbandingan produksi, biaya produksi, penerimaan, dan pendapatan usahatani padi semi organik dan padi non organik dalam satu musim tanam.

\section{METODE PENELITIAN}

Penelitian dilakukan pada bulan Desember 2016 sampai Januari 2017. Pemilihan lokasi dilakukan secara purposive yaitu berdasarkan pada kriteria tertentu, yaitu Kecamatan Undaan, Kabupaten Kudus yang merupakan pusat pertanian padi baik organik maupun non organik (Badan Pusat Statistik, 2016). Kecamatan Undaan dipilih sebagai objek penelitian karena memiliki lahan sawah padi terluas di Kabupaten Kudus dengan luas lahan 8.287 Ha dari total luas lahan sawah padi sebesar 21.204 Ha (Badan Pusat Statistik, 2016).

Jenis penelitian ini adalah penelitian deskriptif kuantitatif. Metode penelitian yang digunakan dalam penelitian ini adalah metode survey untuk responden petani padi non organik dan sensus untuk responden petani padi semi organik. Pengambilan responden dilakukan secara acak untuk responden petani padi non organik sebanyak 41 orang dari populasi sebanyak 410 orang dan sensus untuk responden petani padi semi organik diambil sebanyak 15orang. Data yang digunakan dalam penelitian ini yaitu: 1. Data primer melalui wawancara dengan menggunakan kuesioner; 2. Data sekunder yang diperoleh dari instansi pemerintah atau lembaga terkait. Data primer (identitas responden, luas lahan, jumlah dan jenis penggunaan benih, pupuk, pestisida, tenaga kerja, jumlah produksi, biaya usahatani) dan sekunder (daftar nama dan jumlah kelompok tani, serta jumlah anggota kelompok tani) yang diperoleh, lalu dianalisis dengan uji normalitas data Kolmogorov-Smirnov dan uji beda independent sample t-test melalui program SPSS 16. Pada uji beda independent sample $t$-test jika hasil signifikansinya lebih dari 0,05 maka dapat disimpulkan tidak ada perbedaan nyata antara variabel usahatani padi semi organik dan non organik, sebaliknya apabila hasil uji beda independent sample t-test signifikansinya kurang dari 0,05 maka ada perbedaan nyata antara variabel usahatani padi semi organik dan non organik.

\section{HASIL DAN PEMBAHASAN}

\section{Karakteristik Responden}

Data tingkat pendidikan responden petani padi semi organik dan non organik 
dapat dilihat pada Tabel 1.

Tabel 1 menunjukkan bahwa jumlah responden petani (baik petani padi semi organik dan petani non organik) sebagian besar berasal dari latar belakang pendidikan yang rendah. Latar belakang pendidikan sebagian besar responden yang rendah, dapat dilihat pada data yaitu lulusan SD/MI sebesar $73 \%$ pada petani padi semi organik dan sebesar 56\% pada petani padi non organik. Sebagian besar responden memiliki latar belakang pendidikan yang masih rendah karena warga desa yang bekerja sebagai petani masih kurang mengutamakan pendidikan, selain itu juga karena keterbatasan ekonomi. Tingkat pendidikan seseorang mempengaruhi wawasan dan cara berpikir untuk lebih mengembangkan dan meningkatkan hasil pertanian. Hal ini sesuai dengan pendapat Suprihanto et al. (2003) yang menyatakan bahwa tingkat pendidikan mempunyai fungsi sebagai penggerak sekaligus pemacu terhadap potensi kemampuan sumberdaya manusia dalam meningkatkan kinerja yang dapat dipupuk melalui program pendidikan, pengembangan dan pelatihan.

Tabel 2 menampilkan data jumlah responden petani padi semi organik dan non organik berdasarkan usia. Tabel 2 menunjukkan bahwa $67 \%$ petani padi semi organik dan $41 \%$ petani padi non organik berusia 51-60 tahun. Rata-rata usia petani padi semi organik adalah 53,06 tahun dan rata-rata usia petani padi non organik adalah 53,09 tahun. Responden petani padi semi organik maupun non organik sebagian besar sudah memasuki usia lanjut (non produktif). Kondisi tersebut terjadi karena remaja atau putra/putri petani lebih memilih untuk menjadi buruh atau karyawan pabrik daripada menjadi petani. Hal ini sesuai dengan pendapat Simanjuntak (2001) yang menyatakan bahwa semakin tinggi tingkat umur, maka semakin menurun kualitas kinerja seseorang dan berpengaruh pula pada penurunan produktivitas. Hal tersebut seharusnya menjadi dorongan bagi para petani yang masih berusia muda agar lebih meningkatkan produksinya, karena pada umumnya usia muda (25 sampai dengan 50 tahun) masih tergolong usia yang produktif.

Data luas lahan responden petani padi semi organik dan non organik ditampilkan pada Tabel 3. Luas lahan adalah salah satu faktor produksi yang paling mempengaruhi. Lahan adalah tempat atau media yang digunakan petani untuk menjalankan usahataninya dengan menggunakan satuan pengukuran luas lahan hektar. Rata-rata luas lahan yang digunakan responden petani padi semi organik maupun non organik di Kecamatan Undaan, Kabupaten Kudus adalah 2,3 Ha dan 1,8 Ha. Rata-rata luas lahan yang dimiliki oleh petani responden tersebut lebih luas dibandingkan daerah-daerah lainnya yang ada di Kabupaten Kudus. Luas lahan tentunya harus menyesuaikan dengan faktorfaktor produksi lainnya agar keberlangsungan usahatani yang sedang dilakukan petani terwujud. Hal tersebut sesuai dengan pendapat Daniel (2002) yang menyatakan

Tabel 4. Kuantitas Penggunaan dan Komponen Faktor Produksi

\begin{tabular}{lcrcl}
\hline \multirow{2}{*}{$\begin{array}{c}\text { Penggunaan Komponen } \\
\text { Faktor Produksi }\end{array}$} & \multicolumn{2}{c}{ Rata-rata } & \multirow{2}{*}{$\begin{array}{c}\text { Hasil } \\
\text { Signifikansi }\end{array}$} & \multicolumn{1}{c}{ Keterangan } \\
\cline { 2 - 3 } & Semi Organik Non Organik & $\begin{array}{c}\text { Sigi Beda }(\mathrm{t}) \\
\text { Uji }\end{array}$ & \\
\hline Lahan $\left(\mathrm{m}^{2} / \mathrm{mt}\right)$ & 23.000 & 18.000 & 0,417 & Tidak Signifikan \\
Benih $(\mathrm{kg} / \mathrm{Ha} / \mathrm{mt})$ & 41,2 & 35,96 & 0,283 & Tidak Signifikan \\
Pupuk $(\mathrm{kg} / \mathrm{Ha} / \mathrm{mt})$ & 425,2 & 599 & 0,609 & Tidak Signifikan \\
Pestisida $(1 / \mathrm{Ha} / \mathrm{mt})$ & 4,333 & 7,926 & 0,000 & Signifikan \\
T. Kerja $(\mathrm{Orang} / \mathrm{Ha} / \mathrm{mt})$ & 48 & 59 & 0,012 & Signifikan \\
T. Kerja $(\mathrm{HKP} / \mathrm{Ha} / \mathrm{mt})$ & 339,27 & 292,8 & 0,668 & Tidak Signifikan \\
\hline
\end{tabular}

Sumber: Analisis Data SPSS, 2016 
bahwa luas lahan pertanian merupakan salah satu faktor produksi yang sangat penting dalam proses usahatani, serta lahan yang sempit sudah pasti kurang efisien dibanding lahan yang lebih luas. Semakin sempit lahan usaha, semakin tidak efisien usaha tani yang dilakukan dan begitupula sebaliknya.

\section{Komponen Faktor-Faktor Produksi Usahatani Padi Semi Organik dan Non Organik}

Data kuantitas penggunaan dan komponen faktor produksi responden petani padi semi organik dan non organik dapat dilihat pada Tabel 4 .

Berdasarkan Tabel 4 dapat dilihat bahwa komponen - komponen faktor produksi dan kuantitas rata-rata penggunaan/ musim tanam (mt) pada usahatani padi semi organik maupun non organik sangat bervariasi. Berdasarkan hasil analisis uji beda Independent Sample T-Test penggunaan luas lahan pada usahatani padi semi organik dan non organik diperoleh nilai signifikansi t-test adalah 0,417. Hasil tersebut menunjukkan bahwa uji Independent sample t-test pada luas lahan usahatani padi semi organik dan non organik tidak ada perbedaan signifikan karena nilai signifikansi t-test lebih dari nilai 0,05 $(\mathrm{p}>0,05)$. Hasil menunjukkan bahwa luas lahan petani padi non organik lebih luas daripada luas lahan petani padi semi organik. Kondisi tersebut disebabkan karena luas lahan yang dimiliki dan digunakan oleh petani sangat tergantung pada kemampuan ekonomi masing-masing petani, semakin baik kemampuan ekonomi petani maka semakin luas lahan yang dimiliki atau yang dapat disewa petani untuk berusahatani.

Berdasarkan hasil analisis uji beda Independent Sample T-Test penggunaan benih usahatani padi semi organik dan non organik menunjukkan bahwa penggunaan benih pada usahatani padi semi organik dan non organik tidak ada perbedaan signifikan. Hal tersebut dapat dilihat dari rata-rata penggunaan benih pada usahatani padi semi organik maupun non organik yang tidak menunjukkan perbedaan yaitu sebesar 41,2 kg/musim tanam/Ha dan
35,96 kg/musim tanam/Ha. Besar kecilnya jumlah benih yang digunakan oleh responden petani padi semi organik maupun non organik tergantung pada luas lahan yang dimiliki oleh masing-masing petani dan tergantung pada cuaca atau iklim saat musim tanam. Pada musim tanam pertama yang dilakukan petani saat musim hujan, maka jumlah penggunaan benih oleh petani akan meningkat. Hal tersebut dilakukan untuk menghindari atau memperkecil kemungkinan terjadinya kerugian (penurunan produksi) akibat meningkatnya serangan hama maupun penyakit yang menyerang tanaman padi saat musim hujan. Jenis benih yang digunakan oleh responden petani padi semi organik adalah Benih Padi Ciherang yang digunakan oleh seluruh responden (15 orang) petani padi semi organik, sedangkan jenis benih yang digunakan oleh responden petani padi non organik adalah Benih Padi Ciherang (40 responden) dan Benih Padi Umbukwangi (1 responden). Menurut pendapat Rahim dan Hastuti (2007), benih menentukan keunggulan dari suatu komoditas. Sadjad (1993) menyatakan bahwa benih yang unggul cenderung menghasilkan produk dengan kualitas yang baik dan tahan terhadap penyakit. Semakin unggul dan semakin banyak jumlah benih yang digunakan dalam komoditas pertanian sampai pada batas tertentu, maka semakin tinggi produksi pertanian yang akan dicapai.

Berdasarkan hasil analisis uji beda Independent Sample T-Test penggunaan pupuk pada usahatani padi semi organik dan non organik menunjukkan tidak ada perbedaan. Rata-rata penggunaan pupuk pada usahatani padi semi organik maupun non organik yaitu sebesar 425,2 $\mathrm{kg} / \mathrm{Ha} /$ masa tanam dan 599,05 kg/musim tanam/Ha. Ratarata penggunaan pupuk ini lebih besar jika dibandingkan dengan hasil penelitian dari Suhartini (2013) yang menyatakan bahwa rata-rata penggunaan pupuk pada usahatani padi semi organik adalah sebesar 203,26 $\mathrm{kg} / \mathrm{Ha} /$ musim tanam, sedangkan rata-rata penggunaan pupuk pada usahatani padi non organik adalah sebesar $385,63 \mathrm{~kg} / \mathrm{Ha} / \mathrm{musim}$ 
tanam.

Jumlah penggunaan pupuk $(\mathrm{kg} / \mathrm{Ha} / \mathrm{mt})$ yang digunakan tergantung pada kebiasaan dan ekspektasi petani terhadap produksi yang akan datang serta kondisi kandungan unsur hara tanah, jenis \& macam pupuk yang digunakan tergantung pada kemampuan ekonomi masing-masing responden petani. Jenis pupuk yang digunakan oleh responden petani padi semi organik adalah pupuk kandang, pupuk organik, pupuk kompos, pupuk petroorganik, pupuk mutiara, dan pupuk phonska, sedangkan jenis pupuk yang digunakan oleh responden petani padi non organik adalah pupuk urea, pupuk phonska, pupuk KCL, pupuk TSP, dan pupuk ZA. Muzdalifah (2011), menyatakan bahwa pemberian pupuk dengan komposisi atau takaran yang sesuai dapat menghasilkan produk berkualitas.

Berdasarkan hasil analisis uji beda Independent Sample T-Test, penggunaan pestisida pada usahatani padi semi organik dan non organik menunjukkan terdapat perbedaan signifikan rata-rata penggunaan pestisida pada usahatani padi semi organik maupun non organik yaitu sebesar 4,32 liter/ $\mathrm{Ha} /$ musim tanam dan 7,79 liter/Ha/musim tanam. Hal tersebut menunjukkan bahwa penggunaan pestisida/liter/musim tanam lebih besar pada usahatani padi non organik. Jumlah dan jenis pestisida yang digunakan petani tergantung pada cuaca atau iklim dan kondisi tanaman pada saat musim tanam. Jenis pestisida yang digunakan oleh responden petani padi semi organik adalah spontan, STME (susu; telur; madu; emponempon), fungisida, dan ulate, sedangkan jenis pestisida yang digunakan oleh responden petani padi non organik adalah spontan, starban, topsin, sekor, vertera, privation dan regen cair. Sastroutomo (1992), menyatakan bahwa penggunaan pestisida dengan komposisi dan takaran yang tepat dapat sangat menguntungkan, sedangkan penggunaannya yang berlebihan dan terusmenerus (terutama pada pestisida anorganik) dapat menimbulkan efek yang bersifat negatif baik pada penggunanya, hewan maupun lingkungan sekitar.

Berdasarkan hasil analisis uji beda Independent Sample T-Test, penggunaan tenaga kerja (orang dan HKP) pada usahatani padi semi organik dan non organik, menunjukkan ada perbedaan signifikansi ratarata penggunaan tenaga kerja (orang) pada usahatani padi semi organik maupun non organik yaitu sebesar 48 orang $/ \mathrm{Ha} /$ musim tanam dan 59 orang/ha/musim tanam. Hasil uji Independent sample t-test penggunaan tenaga kerja (HKP) pada usahatani padi semi organik dan non organik tidak ada perbedaan rata-rata penggunaan tenaga kerja (HKP) pada usahatani padi semi organik maupun non organik tidak ada perbedaan signifikansi ratarata penggunaan tenaga kerja (HKP) pada usahatani padi semi organik dan non organik yaitu 339,27 $\mathrm{HKP} / \mathrm{Ha} /$ musim tanam dan $292,80 \mathrm{HKP} / \mathrm{Ha} / \mathrm{musim}$ tanam. Tidak ada tenaga kerja anak-anak dan tenaga kerja wanita yang terlibat dalam usahatani padi semi organik maupun non organik. Jumlah tenaga kerja dan jenis pekerjaan yang dikerjakan tergantung pada luas lahan yang dimiliki/ disewa petani dan juga tergantung pada tingkat kemampuan ekonomi petani. Jenis pekerjaan tenaga kerja yang digunakan oleh responden petani padi semi organik dan

Tabel 5. Hasil Uji Beda Produksi, Biaya Produksi, Penerimaan, dan Pendapatan

\begin{tabular}{lrrcl}
\hline \multirow{2}{*}{$\begin{array}{c}\text { Kalkulasi dalam } \\
\text { /Ha/Mt }\end{array}$} & \multicolumn{2}{c}{ Rata-rata } & Hasil Signifikansi & \multirow{2}{*}{ Keterangan } \\
\cline { 2 - 3 } & Semi Organik & Non Organik & Uji Beda $(\mathrm{t})$ & \\
\hline Produksi (Kw) & 66,40 & 76,45 & 0,108 & Tidak Signifikan \\
Biaya Produksi(Rp) & 8.811 .700 & 15.825 .000 & 0,000 & Signifikan \\
Penerimaan(Rp) & 23.203 .000 & 28.926 .000 & 0,020 & Signifikan \\
Pendapatan (Rp) & 14.392 .000 & 13.101 .000 & 0,606 & Tidak Signifikan \\
\hline
\end{tabular}

Sumber: Analisis Data SPSS, 2016. 
non organik adalah membuat galengan, "ndaud", penanaman bibit, pemupukan, pestisida, penyiangan, penyulaman, dan panen. Lama kerja pada masing-masing pekerjaan usahatani padi semi organik maupun non organik adalah 6 jam. Hal tersebut sesuai dengan pendapat Soekartawi (2003) yang menyatakan bahwa faktor produksi tenaga kerja merupakan faktor produksi yang penting dan perlu diperhitungkan dalam jumlah penggunaan tenaga kerja. Hal itu (jumlah tenaga kerja) saja tidak cukup, tetapi juga kualitas, macam tenaga kerja, dan jenis pekerjaan yang dikerjakan perlu pula diperhatikan untuk mengoptimalkan produksi.

3. Uji Beda Produksi, Biaya Produksi, Penerimaan, dan Pendapatan Usahatani Padi Semi Organik Dan Non Organik

Data hasil uji beda produksi, biaya produksi, penerimaan, dan pendapatan responden petani padi semi organik dan non organik dapat dilihat pada Tabel 5. Produksi adalah sebuah kegiatan yang dikerjakan untuk menghasilkan suatu benda atau menciptakan benda baru sehingga lebih bermanfaat dalam memenuhi kebutuhan. Produksi usahatani padi semi organik dan non organik di Kecamatan Undaan Kabupaten Kudus adalah gabah kering panen atau GKP selama 1 musim tanam per hektar.

Berdasarkan hasil analisis uji beda Independent Sample T-Test produksi usahatani padi semi organik dan non organik menunjukkan tidak ada perbedaan secara signifikan pada rata-rata produksi padi semi organik dan non organik yaitu berturut-turut sebesar 66,40 kw/ha/musim tanam dan 76,45 $\mathrm{kw} / \mathrm{ha} /$ musim tanam. Rata-rata produksi tersebut lebih rendah daripada hasil penelitian Suhartini (2013) dan Mulsanti et al. (2007) yang menyatakan bahwa jumlah produksi gabah kering panen usahatani padi semi organik terutama untuk benih Ciherang adalah sebesar $81,44 \mathrm{kw} / \mathrm{Ha} /$ musim tanam, sedangkan jumlah produksi gabah kering panen usahatani padi non organik terutama untuk benih Ciherang adalah sebesar 76,8 kw/ ha/musim tanam. Banyak faktor yang dapat mempengaruhi jumlah produksi padi semi organik dan non organik, diantaranya adalah jenis tanah, penggunaan jenis dan jumlah benih padi, jenis dan jumlah pupuk, jenis dan jumlah pestisida, serta jumlah tenaga kerja dan jenis pekerjaan usahatani yang harus dikerjakan. Deliarnov (1994) menyatakan bahwa fungsi produksi bisa dilakukan dengan berbagai cara untuk memperoleh output, dapat bersifat input faktor dan labour intensive dengan lebih banyak mengoptimalkan penggunaan faktor produksi dan tenaga kerja atau sistem capital intensive dengan lebih mengoptimalkan penggunaan modal dan mesin-mesin pertanian.

Biaya produksi adalah biaya yang dikeluarkan oleh seorang petani dalam melakukan proses produksi sampai menjadi produk. Biaya produksi pada usahatani padi semi organik maupun non organik di Kecamatan Undaan Kabupaten Kudus antara lain: biaya tetap dan biaya variabel selama satu musim tanam per hektar. Biaya tetap terdiri dari biaya lahan (biaya pajak bumi bangunan /PBB dan biaya sewa lahan) dan biaya penyusutan alat. Biaya variabel terdiri dari biaya benih, biaya pupuk, biaya pestisida, dan biaya tenaga kerja. Berdasarkan hasil analisis Independent Sample T-Test biaya produksi usahatani padi semi organik dan non organik menunjukkan bahwa ada perbedaan nyata rata-rata biaya produksi usahatani padi semi organik maupun non organik yaitu sebesar Rp. 8.811.700,00/musim tanam/ha dan Rp. 15.825.000,00/musim tanam/ha. Menurut hasil penelitian Sari (2011), rata-rata biaya produksi usahatani padi semi organik adalah Rp. 11.369.765,00/musim tanam/ha dan rata-rata biaya produksi usahatani padi non organik adalah Rp. 10.058.508,00/musim tanam/ha. Pada penelitian ini biaya produksi padi semi organik lebih kecil daripada biaya produksi non organik karena jumlah dan jenis beberapa input faktor yang digunakan pada usahatani semi organik (seperti pupuk, pestisida, dan tenaga kerja) lebih kecil atau lebih sedikit dibandingkan usahatani padi non organik. Selain itu input faktor pupuk dan 
pestisida pada usahatani padi semi organik juga ada yang membuat sendiri dan ada yang mendapat subsidi harga dari pemerintah sehingga dapat menekan pengeluaran biaya produksi petani. Berbeda dengan usahatani padi non organik yang sebagian besar input faktornya (seperti pestisida dan pupuk) menggunakan buatan pabrik yang mahal, sehingga biaya produksi usahatani yang harus dikeluarkan juga akan semakin besar. Soekartawi (2002) menyatakan bahwa besar kecilnya jumlah biaya produksi pada usahatani padi semi organik dan non organik, tergantung pada jumlah, jenis, dan harga yang digunakan pada input faktor (biaya variabel dan biaya tetap) pada usahatani tersebut. Semakin banyak dan semakin mahal input faktor yang digunakan, maka biaya produksi usahatani yang harus dikeluarkan juga akan semakin besar.

Berdasarkan hasil analisis Independent Sample T-Test, rata-rata penerimaan usahatani padi semi organik maupun non organik menunjukkan ada perbedaan nyata yaitu sebesar Rp. 23.203.000,00/musim tanam/ha dan Rp. 28.926.000,00/musim tanam/ha. Menurut hasil penelitian Sari (2011), rata-rata penerimaan usahatani padi semi organik adalah Rp. 14.838.263,00/musim tanam/ha dan rata-rata penerimaan usahatani padi non organik adalah Rp. 12.096.533,00/musim tanam/ha. Penerimaan pada usahatani padi semi organik maupun non organik di Kecamatan Undaan Kabupaten Kudus adalah penerimaan dari hasil perkalian dari jumlah produksi (Quantity GKP) dengan harga jual produksi (Price GKP), dimana penerimaan usahatani tersebut adalah hasil dari seluruh penjualan produk (GKP) yang diterima oleh petani. Mubyarto (1989) menyatakan bahwa penerimaan usahatani merupakan hasil perkalian antara produksi dengan harga jual. Penerimaan/musim tanam/ha pada usahatani padi semi organik lebih kecil dibandingkan dengan penerimaan usahatani padi non organik, karena produksi dan harga jual gabah kering panen (GKP) lebih rendah daripada usahatani padi non organik. Hal ini dapat terjadi karena pembeli gabah kering panen
(GKP) adalah penebas yang melihat kondisi lahan panen padi sawah semi organik kurang menarik, sehingga harga jual GKP padi semi organik lebih rendah daripada harga jual GKP padi non organik.

Pendapatan pada usahatani padi semi organik dan non organik di Kecamatan Undaan Kabupaten Kudus adalah hasil pengurangan dari penerimaan usahatani dengan biaya produksi usahatani. Soekartawi (2002) menyatakan bahwa pendapatan usahatani juga dapat didefinisikan sebagai sisa dari pengurangan nilai penerimaan yang diperoleh dari biaya yang dikeluarkan. Hasil analisis uji beda Independent Sample T-Test menunjukkan tidak ada perbedaan signifikansi rata-rata pendapatan usahatani padi semi organik maupun non organik sebesar Rp. 14.392.000,00/musim tanam/ha dan Rp. 13.101.000,00/musim tanam/ha.

Hasil penelitian Sari (2011) menemukan bahwa rata-rata pendapatan usahatani padi semi organik adalah Rp. 3.468.497,00/musim tanam/ha dan rata-rata penerimaan usahatani padi non organik adalah Rp. 2.038.025,00/musim tanam $/$ ha. Pendapatan usahatani merupakan profit atau keuntungan yang didapatkan petani padi semi organik maupun non organik untuk mencukupi kebutuhan hidup dan kebutuhan keluarga. Pendapatan usahatani padi semi organik cenderung lebih besar daripada usahatani padi non organik, karena selisih penerimaan dengan biaya produksi usahatani padi semi organik cenderung lebih besar dibandingkan dengan usahatani padi non organik. Rata-rata penerimaan usahatani padi non organik lebih besar daripada semi organik tetapi rata-rata biaya produksi jauh lebih tinggi, sehingga rata-rata pendapatannya cenderung lebih kecil dibandingkan usahatani semi organik. Rahim dan Hastuti (2007) menyatakan bahwa pendapatan usahatani merupakan bentuk balas jasa dan kerja sama dari faktor -faktor produksi lahan, tenaga kerja, modal, dan pengelolaan. Mubyarto (1989) menyatakan bahwa masalah pokok yang dihadapi petani adalah rendahnya tingkat pendapatan akibat produktivitas tanaman yang rendah, harga jual 
produk (GKP) yang fluktuatif, serta naiknya biaya produksi.

\section{SIMPULAN DAN SARAN}

Komponen faktor-faktor produksi yang digunakan pada usahatani padi semi organik maupun non organik adalah luas lahan, benih, pupuk, pestisida, dan tenaga kerja. Kuantitas rata-rata faktor produksi lahan, benih, pupuk, dan tenaga kerja (orang/ha/mt) tidak ada perbedaan dalam satuan per hektar per musim tanam, sedangkan kuantitas rata-rata faktor produksi pestisida dan tenaga kerja (HKP/ha/ $\mathrm{mt})$ terdapat perbedaan nyata.

Pada biaya produksi dan penerimaan usahatani padi semi organik dan non organik terdapat perbedaan nyata dalam satuan perhektar/mt, dimana biaya produksi dan penerimaan lebih besar usahatani padi non organik daripada semi organik. Pada produksi dan pendapatan tidak ada perbedaan nyata dalam satuan perhektar.

Berdasarkan hasil penelitian analisis komparasi usahatani padi semi organik dan non organik di Kecamatan Undaan Kabupaten Kudus, saran yang dapat diberikan adalah bahwa petani padi semi organik dapat menambah atau meningkatkan harga jual gabah kering panen untuk meningkatkan penerimaan dan pendapatan usahatani padi semi organik dan diserahkan kepada penebas. Upaya yang dapat dilakukan adalah dengan cara meningkatkan produksi GKP dan kualitas hamparan lahan atau dengan meningkatkan tingkat usahatani dari usahatani semi organik ke usahatani organik.

\section{DAFTAR PUSTAKA}

Badan Pusat Statistik. 2016. Kabupaten Kudus Dalam Angka Tahun 2015. BPS. Kabupaten Kudus

Badan Pusat Statistik. 2016. Kecamatan Undaan Dalam Angka Tahun 2016. BPS. Kabupaten Kudus

Daniel. 2002. Pengantar Ekonomi Pertanian. Bumi Aksara. Jakarta.

Deliarnov. 1994. Teori Ekonomi Mikro. Prinsip Dasar dan Pengembangannya. Disadur dari buku aslinya
Microeconomic Theory Basic Principles and Extention. Cetakan Ketiga. PT Raja Grafindo Persada. Jakarta.

Mubyarto. 1989. Pengantar Ekonomi Pertanian. LP3ES. Jakarta

Mulsanti, I.W., S. Wahyuni, dan A. Setyono. 2007. Pengaruh kecepatan putar silinder mesin perontok terhadap mutu benih padi. Prosiding Seminar Apresiasi Hasil Penelitian Padi Menunjang P2BN. Buku (2): 947 - 958.

Muzdalifah. 2011. Analisis produksi dan efisiensi usahatani padi di Kabupaten Banjar. J. Agribisnis Perdesaan. 4(2): 50-51.

Rahim, A. dan D.R.W. Hastuti. 2007. Ekonomi Pertanian. Penebar Swadaya. Jakarta.

Sadjad, S. 1993. Dari Benih Kepada Benih. Gramedia. Jakarta.

Sari, I. N. 2011. Analisis Ekonomi Usahatani Padi Semi Organik Dan Anorganik Pada Petani Penggarap. Institut Pertanian Bogor. Bogor. (Skripsi)

Sastroutomo, S. 1992. Pestisida Dasar-dasar dan Dampak Penggunaannya. Gramedia Pustaka Utama. Jakarta

Simanjuntak, P. J. 2001. Ekonomi Sumber Daya Manusia. Lembaga Penerbit Fakultas Ekonomi Universitas Indonesia. Jakarta.

Soekartawi. 2002. Analisis Usaha Tani. UIPress. Jakarta

Soekartawi. 2003. Teori Ekonomi Produksi dengan Pokok Bahasan Analisis CobbDouglas. Grafindo Persada. Jakarta.

Suhartini. 2013. Kualitas lingkungan pada usahatani padi semi organik dan non organik serta dampaknya terhadap produktivitas padi di Kabupaten Sragen, Jawa Tengah. Habitat. 14 (1): 86 - 89.

Suprihanto, J., T. Harsiwi, M. Agung, H. Prakosa. 2003. Perilaku Organizational. Cetakan Pertama. Bagian Penerbitan Sekolah Tinggi Ilmu Ekonomi. Yogyakarta.

Suratiyah, K. 2008. Ilmu Usahatani. Penebar Swadaya. Jakarta. 